\title{
Demography, Land Utilization And Livelihoods In Sarangkot Village Development Committee Of Kaski District, Nepal
}

\author{
Narayan P. Bhusal \\ Reader Department of Geography Education
}

T.U., Nepal

\begin{abstract}
Poverty alleviation has always remained as a major challenge for overall development in Nepal and Sarangkot Village Development Committee (VDC) in Kaski district also is under such circumstances where tourism and other offfarm economic activities would be the successful vehicles for overall development. Availability of better demographic conditions, sustainable agricultural production system and proper utilization of existing resources for the development of off-farm economic activities are the important livelihood assets. It is in this light this paper is trying to present the demographic conditions, land use pattern, agricultural production from the cultivated land, livestock raising and food sufficiency from the production of land in Sarangkot VDC. As the survey result indicated that the food sufficiency from the production of land is not sufficient in order to maintain the livelihood conditions of the local people. Therefore, this paper also deals about the available off-farm economic activities that are supporting for the economic welfare of the people.
\end{abstract}

Key Words: Population, sustainable, livelihood assets, agriculture, off-farm economic activities eco-tourism

\section{INTRODUCTION}

Sustainable livelihood is achieved through access to a range of livelihood resources (natural, economic, human and social capitals) which are combined in the pursuit of different livelihood strategies (Ian, 1998). The use of land provides a key link between human activity and the natural environment. Although land is a resource; it is different, it is peculiar, and it is not the same as other resources that support our economy, society and livelihoods (Owens, 2007). A livelihood comprises the capabilities, assets (including both material and social resources) and activities required for a means of living (Chambers and Conway, 1991). People's ability to escape poverty depends on access to assets. Livelihood is affected by the diversity and amount of assets and the balance between assets. Assets help to determine livelihood options and that are transformed into livelihood outcomes. Many rural dwellers in Nepal are dependent on land for subsistence agriculture and faced with a booming population and a rapidly deteriorating natural environment, the call for alternative and sustainable livelihood options has become the need of the day (Campbell, 2008). Sarangkot VDC is located in the north-west part of Pokhara Sub-Metropolitan City where the land is extended from $500 \mathrm{~m}$ adjoining Pokhara valley in the east to $1590 \mathrm{~m}$ of altitude towards the west at Sarangkot Hill-Top, one of the most important tourism sites in Pokhara Valley (Bhusal, 2o10). Because of the unfavorable slopes the agricultural production from the available agricultural land is not sufficient for the subsistence of the people. Therefore, employment opportunities with the urban functions in Pokhara and promotion of tourism related economic activities in the VDC are more promising alternative livelihood options for the people living in the VDC. It is in this light the present paper is an attempt to familiarize the demographic picture, land utilization for agricultural production and livelihood options for the people living in.

\section{STUDY AREA}

Sarangkot is one of the 43 VDCs in Kaski district that lies to the northwest of Pokhara Sub-Metropolitan City in the central part of the Western Development Region of Nepal. This VDC covers 1625 sq. km. of area that borders the Hemja VDC in the north, Pokhara Sub-Metropolitan City in the south and east, Kaskikot and Chapakot in the west. The altitude of this VDC ranges from $500 \mathrm{~m}$ to $1590 \mathrm{~m}$ above the mean sea level (amsl) (Fig.1). In the upper part of the VDC bedrock is more metamorphosed than in the lower part. Soils are widely variable whereas lower part of the VDC is a region of moderately metamorphosed sedimentary materials and soils are extremely variable reflecting differences in bed rock, geomorphology, micro-climate and land use. Slopes of up to 30 degrees are terraced using traditional methods. 
In general the sub-tropical climate exists in the area below the altitude of $1500 \mathrm{~m}$; temperate climate exists from $1500 \mathrm{~m}-2000 \mathrm{~m}$ amsl. Almost all the northern flank of the VDC is covered by dense forest that makes the green and natural surrounding attractive and amusing. Natural vegetation varies with altitude ranging from subtropical rain forest to temperate. The dominating vegetation species are Schima wallichi, Castamopsis indica, Bombax ceiba, and so on. Shorea robusta is found to some extend in the lower parts and as the altitude increase the species of temperate vegetation are the dominant.

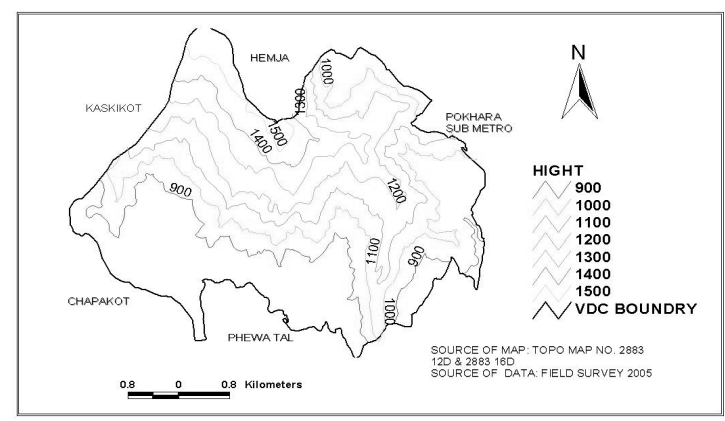

Figure 1: Sarangkot Village Development Committee in Kaski District

According to local residents, the number of wild life is increasing gradually in this VDC as per the growth of species and extension of forest density. At present, this VDC has been the shelter of common leopard, jungle cat, crab eating mongoose, and birds like cattle egret, kingfishers, barbets, dark kite, black partridge,, sparrow, crow, jungle fowl, partridge, dove, pheasants and so on. Harpan Khola, Yamdi Khola and Seti River are the major perennial water bodies that are drained the VDC. Fewa Lake that lies in the southwest boarder of the VDC is the wonderful view from the Sarangkot hill and the major attraction for the tourists who visits in Pokhara.

\section{METHODS AND MATERIALS}

Rapid/participatory method was used in order to collect relevant data and information from the study area. In order to collect the data and information A resource survey format was developed. A number of group meetings were organized in different wards of the VDC in order to collect the necessary information. Besides, relevant data and information were collected from Sarangkot VDC office, schools, health post, mother groups, forest user's groups, local clubs and NGOs that are located in the VDC. Available maps and air photos of different time periods had been taken for field verification and update. On the basis of field verification, a map of land utilization was prepared by applying Geographic Information System (GIS).

\section{POPULATION DISTRIBUTION}

According to the census taken by the Sarangkot VDC in 2005 the total population was 6,787 that constituted 53 percent female and 47 percent male population. As shown in Table 1, the child population from the age of 0 to 5 was 1,080 of which 54 percent represented girls. The school going population from the age of 6 to 16 was 1,675 and in this age group male population dominates (53 percent). The economically active population from the age of 17 to 65 was 3,417 (female: 1862 male: 1555). The population of elderly people, above 65 of age, was 615. In this age group female population (53 percent) was higher than male population (47 percent).

Table 1: Population by age and gender

\begin{tabular}{|l|c|c|c|c|c|}
\hline Age-group & $0-5$ & $6-16$ & $17-65$ & Over 65 & Total \\
\hline Male & 501 & 881 & 1555 & 266 & 3203 \\
\hline Percentage & 46.38 & 52.59 & 45.50 & 43.25 & 47.19 \\
\hline Female & 579 & 794 & 1862 & 349 & 3584 \\
\hline Percentage & 53.92 & 47.41 & 77.03 & 56.74 & 52.51 \\
\hline Total & 1080 & 1675 & 3417 & 615 & 6787 \\
\hline Percentage & 15.92 & 24.67 & 50.34 & 9.07 & 100.0 \\
\hline
\end{tabular}

\section{ETHNIC COMPOSITION}

In this VDC, altogether 1052 households (HHs) with 11 ethnic groups were found, there distribution is presented in Table 2 . The average family size for all the groups was 7 members, the highest being 8 of Gurung and Magar and the lowest 6 for Brahman and Chhetri. 
Table 2: Ethnic groups by household and family size

\begin{tabular}{|l|c|c|c|c|c|c|}
\hline \multirow{2}{*}{ Ethnic Group } & \multirow{2}{*}{ Family Size } & \multicolumn{2}{|c|}{ No. of HH } & \multicolumn{3}{|c|}{ No. of People } \\
\cline { 3 - 7 } & & No & Percent & Male & Female & Total \\
\hline Brahmin & 6 & 380 & 36.1 & 1065 & 1215 & 2280 \\
\hline Chhetri & 6 & 413 & 39.3 & 1139 & 1339 & 2478 \\
\hline Gurung & 8 & 9 & 0.9 & 30 & 37 & 672 \\
\hline Magar & 8 & 43 & 4.1 & 143 & 158 & 301 \\
\hline Others & 7 & 207 & 19.7 & 787 & 869 & 1656 \\
\hline Total & 7 & 1052 & 100.0 & 3164 & 3618 & 6783 \\
\hline
\end{tabular}

Source: Village Survey, 2005.

\section{MIGRATION}

In the last 10 years, altogether 21 households of Brahman and Chhetri ethnic groups were reported to be out migrated permanently from this VDC to Chitwan, Bardia and Kathmandu for economic and social reasons. Likewise, in last 10 years 13 households of Brahman, Chhetri, Rai, Newar and Gurung ethnic groups were in-migrated permanently from Parbat, Shyangja and VDCs of Kaski districts to this VDC for economic reasons. Temporary and seasonal migration of young population to the urban centers of Nepal, India and other third world countries for livelihood earnings is a regular phenomenon.

\section{RELIGIONS}

Like other villages of Nepal the Hinduism and Buddhism are the common religions of the population. Gurung, Tamang, Thakali and Rai population perform their own socio-cultural activities and regular ceremonies that are based on Buddhism whereas other ethnic groups such as Brahmin, Chhetri, Newar, Damai, Kami and Sarki are the follower of Hindu religion. There are some $\mathrm{HH}$ who follows the Christian religion too.

\section{FESTIVALS}

Dashain, Tihar, Maghesakranti, Chaite Dashain, Baisakh Sakranti (New Year Day), Ashadh Pandra, Saune Sankranti, Krishna Janmastami, Teej etc. are the major festivals are also the common festivals for the Hindu Community that are also celebrated by the Buddhist people as well. Losar (Paush Pandra) and Buddha Purnima (Baisakh Purnima) are the major and most important festival of the Buddhist population specifically the Gurung community.

\section{LANGUAGE}

Almost all people in this VDC speak Nepali. Gurung and Newar ethnic groups may also speak their own language but Nepali is common. Also young generation can speak English and Hindi languages that is supporting while tourists visit in their area.

\section{EDUCATION}

Of the total population 64 percent of this VDC above the age of 6 were reported to be literate. Altogether two secondary, two lower secondary and six primary levels (including two privately managed schools) of educational institutions are distributed in different wards of this VDC. One Sanskrit school by the name of Chisa Khola Veda Vidyashram (Sanskrit School for teaching Hindu rites and rituals) is located in Chisa Khola. Two Children Development Centers are located in this VDC for the welfare of children. As the VDC is close to Pokhara where most of the students go for their further education or even for secondary education and about nine percent of the total population is recorded with the education of above SLC level.

Of the total students $(1,941)$ enrolled for the year 2005 in the different level (Primary to Secondary) of education, 1027 (52.9 percent) are girls and 914 (47.1 percent) are boys (Table 3).The number of student enrollment in the primary, lower secondary and secondary level is recorded as 591, 120, and 1,230 respectively in that year. The proportion of the girl enrollments in the schools is higher as that of the boys, which indicates the local people's awareness regarding the right of education for the girls. 
Table 3: Number of students by level and gender

\begin{tabular}{|l|c|c|c|c|c|c|}
\hline \multirow{2}{*}{ Level } & \multicolumn{3}{|c|}{ Number of Students } \\
\cline { 2 - 7 } & \multicolumn{2}{|c|}{ Male } & \multicolumn{2}{c|}{ Female } & \multicolumn{2}{c|}{ Total } \\
\cline { 2 - 7 } & No. & Percentage & No. & Percentage & No. & Percentage \\
\hline Primary & 278 & 30.4 & 313 & 30.5 & 591 & 30.4 \\
\hline $\begin{array}{l}\text { Lower } \\
\text { Secondary }\end{array}$ & 50 & 5.4 & 70 & 6.8 & 120 & 6.2 \\
\hline Secondary & 586 & 64.1 & 644 & 62.7 & 1230 & 63.4 \\
\hline Total & 914 & 47.1 & 1027 & 52.9 & 1941 & 100.0 \\
\hline
\end{tabular}

Source: Village Survey, 2005

\section{HEALTH}

There is a sub-health post located in ward no. 3 of this VDC where two working technical staff: a Health Assistant and a Nurse are serving to the local people for the minor treatment (Table 4). This subhealth post often organizes health and sanitation awareness programmes, basic vaccination, motherchild services, nutrition programmes and family planning advice services. A Village Household
Clinic Programme is also implementing by this health post in every month in different villages of the VDC to serve local population For the treatment of the major diseases, a number of medical facilities (private and public hospitals, nursing homes and clinics) are available in Pokhara Bazaar that is easily accessible from this VDC.

Table 4: Health situation

\begin{tabular}{|l|l|l|c|}
\hline & Health post & Hospital & Dhami/Jhakri \\
\hline Nearest medical care & Yes & No & No \\
\hline Location of medical care & Ward NO-3 & - & - \\
\hline Distance from VDC office & $3 \mathrm{KM}$ & - & NO \\
\hline No of Doctor/Health In-charge & 1 Health Assistant & - & - \\
\hline No. of Nurse & 1 Mashika & - & - \\
\hline Present status of Medical care & Good & - & - \\
\hline Name of dieses prevailing & $\begin{array}{l}\text { Cold, Cough, Diahoria } \\
\text { etc. }\end{array}$ & & \\
\hline
\end{tabular}

Source: Village Survey, 2005.

\section{DRINKING WATER SUPPLY AND SANITATION}

Out of the total household $(1,052)$ in this VDC, about 78 percent $\mathrm{HH}$ is served by piped drinking water system, 15 percent $\mathrm{HH}$ fetch their drinking water from spout and 7 percent $\mathrm{HH}$ from the stream (Table 5). A total of 33 water supply systems are supplying 338 water taps in different wards of the VDC.
The water supply system that was supported by Lions Club has not been functioning properly (in ward no. 1,3 and 8) due to lack of proper maintenance and damage caused by the road construction. Only 29 percent of the total population has access to toilet facility and rest of the people are using open grounds/riversides for the toilet purpose 
Table 5: Drinking water supply

\begin{tabular}{|c|c|c|c|c|c|c|c|c|c|c|}
\hline \multirow[t]{2}{*}{ Water Source } & \multicolumn{9}{|c|}{ No. of HH Access to Drinking Water in Ward No. } & \multirow{2}{*}{$\begin{array}{c}\text { Total } \\
(\% \text { Of total } \\
\mathrm{HH})\end{array}$} \\
\hline & 1 & 2 & 3 & 4 & 5 & 6 & 7 & 8 & 9 & \\
\hline Piped & 20 & 85 & 33 & 66 & 275 & 110 & 80 & 60 & 90 & $819(77.9)$ \\
\hline Well/Spout & 12 & 15 & - & 16 & 18 & 44 & 13 & 28 & 12 & $158(15.0)$ \\
\hline River/Stream & - & 5 & - & 30 & 25 & 5 & 10 & $\mathrm{NO}$ & No & $75(7.1)$ \\
\hline Total & 32 & 105 & 33 & 112 & 318 & 159 & 103 & 88 & 102 & $1052(100)$ \\
\hline No. of System & 5 & 7 & 4 & 2 & 5 & 3 & 2 & 3 & 2 & 33 \\
\hline No. of tape & & $\begin{array}{l}42 \\
55 \\
40\end{array}$ & & 27 & 51 & 36 & 17 & 30 & 40 & 338 \\
\hline
\end{tabular}

Source: Village Survey, 2005.

\section{SETTLEMENT}

In this VDC distribution of settlement is concentrated more in the southern and eastern slopes that is dispersed in nature and linear/nucleated along the Bindabasini-Sarangkot road. The distribution of settlement in different wards is presented in Table 6.

Table 6: Distribution of settlement

\begin{tabular}{|l|l|}
\hline Ward No. & Name of settlement \\
\hline 1 & $\begin{array}{l}\text { Sarangkot,Deurali,Patan,Haredanda } \\
\text {,Dhakaltar, }\end{array}$ \\
\hline 2 & Khatrithar, Pandeli,Kharpaudi \\
\hline 3 & Simtal, Kamigaun, \\
\hline 4 & Khadkathar, Bhakundebagar \\
\hline 5 & $\begin{array}{l}\text { Toripani,Bhanjyang,Aramja, } \\
\text { Chankhapur }\end{array}$ \\
\hline 6 & Netachautari,Nayabasti,Methalang, \\
\hline 7 & Gyarjati,Shiva Bhanjyang,Setibar \\
\hline 8 & Gothadi,Dharakopandhera \\
\hline 9 & $\begin{array}{l}\text { Bindeshwaripakha,Lamagaun, } \\
\text { Gharelu }\end{array}$ \\
\hline
\end{tabular}

Source: Field Survey, 2005

Sarangkot hill area is the main tourism trade centre. Other tourism trade centers (settlements) along the road side (hiking route) from the Bindabasini temple (east of Sarankot) are Lamagaun, Rohotepani, Gharelu, Binacular, Gothadi and Simsare. A number of lodges/restaurants, provisional shops, fruit shops, curio good shops and so on are distributed in order to provide the services for tourists and in return the people from these settlements are maintaining their livelihoods so far.

\section{LAND UTILIZATION}

Access to land for agriculture is obviously important within a largely agrarian society. Also important is what people can do with that land. Aerial photographs of 1:50,000 scale taken in 2001 by the Department of Survey of of Nepal Government were used for the preparation of the land use map and field checks were undertaken during the field survey. The area of major land use categories such as cultivated land, forest land, grass land, swamp and lake area are presented in Table 7 and Fig. 2.

\section{Table 7: Land utilization}

\begin{tabular}{|l|c|c|}
\hline Land Use Type & $\begin{array}{c}\text { Area in Square } \\
\text { Km. }\end{array}$ & $\begin{array}{c}\text { Area in } \\
\text { Percentage }\end{array}$ \\
\hline Cultivated land & 12.94 & 59.6 \\
\hline Forest land & 7.08 & 32.6 \\
\hline Grass land & 0.84 & 3.9 \\
\hline Swamp & 0.72 & 3.3 \\
\hline Lake & 0.12 & 0.6 \\
\hline Total & 21.6 & 100.0 \\
\hline
\end{tabular}

Source: Air Photo of 2001 and Field Check, 2005.

Access to land for agriculture is obviously important within a largely agrarian society. Also important is what people can do with that land. 


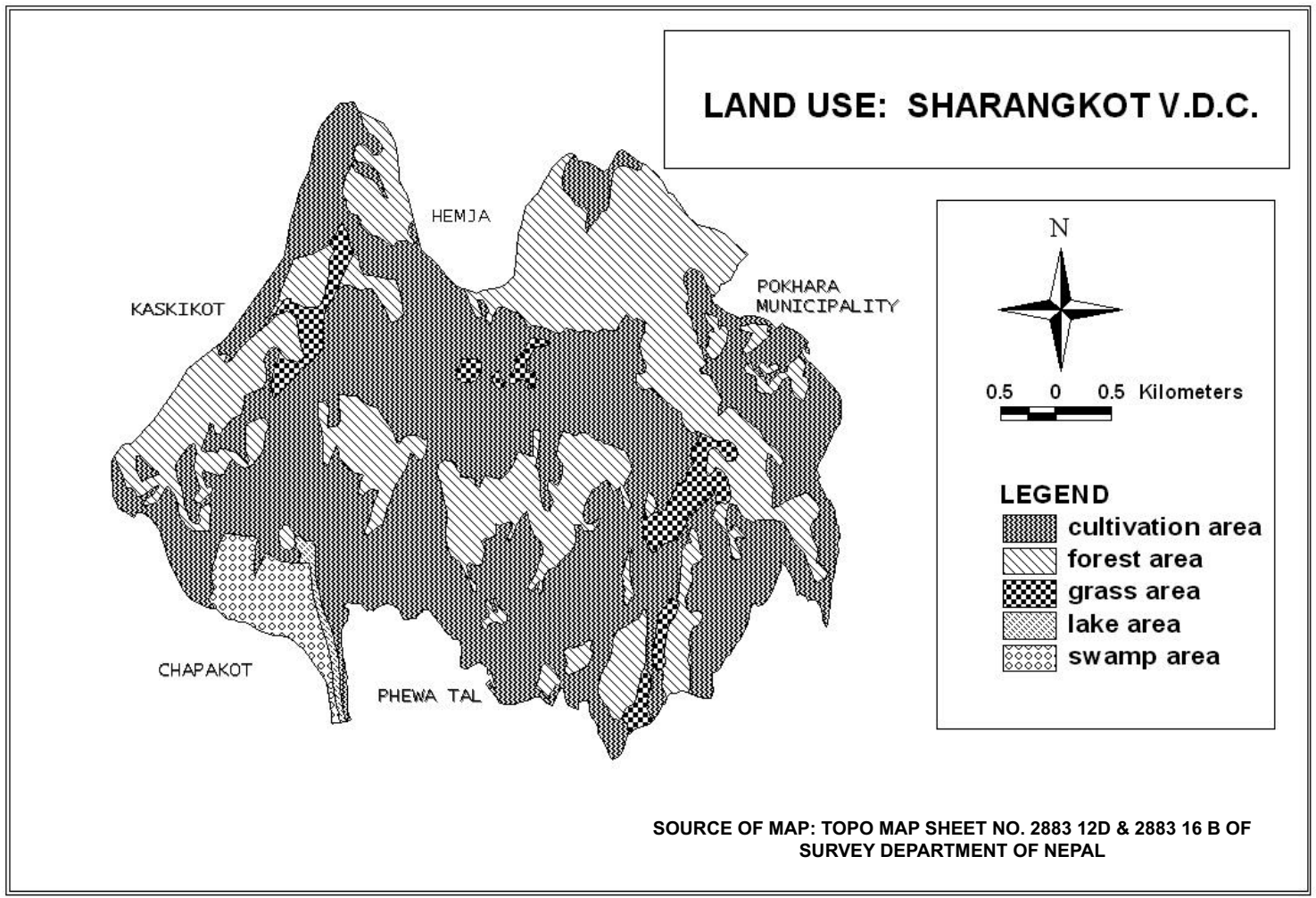

Figure 2

\section{LAND OWNERSHIP}

As shown in Table 8 land ownership distributions in this VDC are uneven. According to the data solicited from the group discussion, 11.6 percent of the total households own more than 20 Ropani, while 32.5 percent of the farmers owned up to 20 Ropani of land. Of the total households 39.9 percent hold 5 to 10 Ropani and 11.4 percent owned up to 5 Ropani of land. Altogether there are 48 households (11 percent) that have no land. Therefore most of them work as laborer in the VDC and in the Bazaar area for their livelihood. The table indicates that people in this area are not holding sufficient amount of land. In other words, agricultural production from the land is not sufficient for the population living in the VDC.

\section{Table 8: Land ownership pattern}

\begin{tabular}{|l|c|c|c|c|c|c|c|c|c|c|}
\hline \multirow{2}{*}{ Land Holdings } & \multicolumn{9}{|c|}{ No. of HH in Ward No. } & \multirow{2}{*}{$\begin{array}{c}\text { Total } \\
\text { (\% of totalHH) }\end{array}$} \\
\cline { 2 - 12 } & 1 & 2 & 3 & 4 & 5 & 6 & 7 & 8 & 9 & $120(11.4)$ \\
\hline 1-5 Ropani & 14 & 31 & 31 & 4 & 7 & 1 & 7 & 7 & 8 & $420(39.9)$ \\
\hline 5-10 Ropani & 15 & 21 & 16 & 36 & 205 & 55 & 50 & 12 & 10 & $342(32.5)$ \\
\hline 10-20 Ropani & 5 & 28 & 18 & 21 & 36 & 21 & 51 & 23 & 39 & $122(11.6)$ \\
\hline $\begin{array}{l}\text { Above } \\
\text { Ropani }\end{array}$ & - & 26 & 2 & 3 & 7 & 4 & - & 34 & 46 & $48(4.6)$ \\
\hline Landless & 6 & - & - & 5 & 15 & 5 & 6 & 5 & 6 & $1052(100.0)$ \\
\hline Total & 40 & 106 & 67 & 69 & 270 & 96 & 214 & 81 & 109 & 16 \\
\hline
\end{tabular}

(1 ropani $=508.5$ sq.m or 19.66 ropani -1 ha) 


\section{LAND TENURE}

In this VDC about 17 percent of the total households (some of them include land less households) are renting in and 13 percent are renting out their land for food grain production (Table 9). For the sake of accessibility, some households renting other's land close to their home and renting out their owned land located at the farther distance.

Table 9: Land tenure

\begin{tabular}{|l|c|c|c|c|c|c|c|c|c|c|}
\hline \multirow{2}{*}{ Type } & \multicolumn{7}{|c|}{ No. of HH in Ward No. } & \multirow{2}{*}{$\begin{array}{c}\text { Total } \\
(\% \text { of Total HH) }\end{array}$} \\
\cline { 2 - 12 } & 1 & 2 & 3 & 4 & 5 & 6 & 7 & 8 & 9 & 15 \\
\hline Renting in others land & 20 & 40 & 33 & 15 & 20 & 19 & 10 & 4 & 15 & $176(16.7)$ \\
\hline Renting out the land & 12 & 25 & 49 & 10 & 5 & 19 & 10 & 4 & 15 & $159(15.1)$ \\
\hline
\end{tabular}

Source: Village Survey, 2005

\section{CROPPING CALENDAR}

March, April, May and June are the busiest months of the year, as plantation of paddy, maize and millet takes place. August, September and October are the second busiest months, with the harvesting of maize, millet (August) and paddy (September and
October). Weeding activities of the different crops takes place in the months of February (potato), March, April (wheat), May, June (maize and millet) and July and August for paddy (Table 10).

Table 10: Cropping calendar

\begin{tabular}{|l|l|l|l|}
\hline Crops & Plantation Date & Weeding Date & Harvesting Date \\
\hline 1. Paddy & May, June, July & July, August & September, October \\
\hline 2. Maize & March, April & May, June & August \\
\hline 3. Millet & May, June & May, June & August \\
\hline 4.Wheat & October, November & March, April & March, April \\
\hline 5.Potato & November, December & February & March \\
\hline
\end{tabular}

Source: Village Survey, 2005.

\section{PRODUCTIVITY OF LAND}

Like other agricultural villages of Nepal, chemical fertilizer and improved seeds are used for paddy, maize, wheat, potato and different vegetable productions. According to the local people, sometimes excessive use of chemical fertilizer has the negative impact on the productivity of the soil, therefore not more than necessary quantity of chemical fertilizer is recommended to use for the particular crop production in order to maintain the productivity of the soil.

\section{CROP PRODUCTION}

Major crops grown in this VDC are paddy, maize, millet, wheat and potato and households growing different crops, area covered by the crops, productivity of different crops and total production are presented in Table 11. 
Narayan P. Bhusal... DEMOGRAPHY, LAND UTILIZATION AND LIVELIHOODS IN SARANGKOT VILLAGE/29

Table 11: Production and productivity of different crops

\begin{tabular}{|l|c|c|c|c|}
\hline \multicolumn{1}{|c|}{ Crops } & $\begin{array}{c}\text { No. of HH growing } \\
\text { of total HH) }\end{array}$ & Area in Ropani & $\begin{array}{c}\text { Production/ } \\
\text { Ropani }\end{array}$ & Total Production \\
\hline Paddy & $130(12.4)$ & 390 & 1.81 Muri & 705 Muri \\
\hline Maize & $180(17.1)$ & 540 & 1.67 Muri & 902 Muri \\
\hline Millet & $23(2.2)$ & 69 & 1.30 Muri & 90 Muri \\
\hline Wheat & $280(26.6)$ & 840 & 1.66 Muri & 1392 Muri \\
\hline Potato & $53(5.0)$ & 159 & 200 Muri & 31800 Muri \\
\hline
\end{tabular}

1 muri $=90.9$ liter

Source: Village Survey, 2005

\section{FOOD SUFFICIENCY}

So far as the food sufficiency from the agricultural production in the VDC is concerned, approximately 20 percent of the households have sufficient supplies for up to three months, 27 percent for 3 to 6 months, 30 percent for 6 to 9 months and 21 percent for 9 to 12 months. And only 2.2 percent have food secure and sell surplus (Table 12).

Table 12: Status of food sufficiency

\begin{tabular}{|l|c|c|c|c|c|c|c|c|c|c|}
\hline \multirow{2}{*}{$\begin{array}{l}\text { Agr. Production } \\
\text { Sufficient for: }\end{array}$} & \multicolumn{9}{|c|}{ No. of HH in Ward No. } & \multicolumn{2}{c|}{$\begin{array}{c}\text { Total (\% Of } \\
\text { total HH) }\end{array}$} \\
\cline { 2 - 12 } & 1 & 2 & 3 & 4 & 5 & 6 & 7 & 8 & 9 & $207(19.6)$ \\
\hline Upto 3 Months & 7 & 16 & 12 & 25 & 20 & 33 & 12 & 25 & 57 & $288(27.4)$ \\
\hline 3-6 Months & 21 & 31 & 32 & 20 & 90 & 25 & 29 & 15 & 25 & $317(30.1)$ \\
\hline 6-9 Months & 8 & 35 & 19 & 20 & 80 & 35 & 35 & 35 & 50 & $219(20.7)$ \\
\hline 9-12 Months & 11 & 33 & 19 & 24 & 35 & 24 & 25 & 27 & 19 & $23(2.2)$ \\
\hline Enough to Sell & - & - & - & 5 & 10 & 5 & - & - & 3 & $1052(100.0)$ \\
\hline Total & 47 & 115 & 82 & 94 & 235 & 122 & 101 & 102 & 154 & \\
\hline
\end{tabular}

Source: Village Survey, 2005

\section{HORTICULTURE/KITCHEN GARDEN}

Main fruits grown in this VDC are banana, pineapple orange papaya mango, guava and so on. The fruits produced in this VDC are mainly for local consumption and to some extent orange and other fruits are supplying to the restaurants for tourist. Majority of the households in this VDC produce the different type of vegetable and main vegetables grown in this area are cauli-flower, radish, green sag, garlic, tomato and so on. Majority of the household produce green vegetables for own consumption and only a small number of farmers along the border sides of the Pokhara Sub-Metropolitan City are supplying to the local vegetable market.

\section{LIVESTOCK}

Animal husbandry plays an important role in the economy of the people in this VDC. This activity is also important in crop production because livestock are required for draft power and manure for crop production and ghee, milk and meat for household consumptions. As presented in Table 13, the livestock reared in this VDC are cow (1315), oxen (1938), buffalo (1278), goat (2684), (pig 195) and chicken/duck (4025). One of the major sources of income for the household expenses comes from the sale of animal products such as milk and ghee from cow and buffalo, meat from goat, pig and chicken/ duck/eggs. Market for the animal products is easily accessible and available that is Pokhara Bazaar. 
Table 13: Distribution of livestock

\begin{tabular}{|l|c|c|c|c|c|c|c|c|c|c|}
\hline \multirow{2}{*}{ Name } & \multicolumn{9}{|c|}{ No. of Livestock in Ward No. } & \multirow{2}{*}{ Total } \\
\cline { 2 - 11 } & 1 & 2 & 3 & 4 & 5 & 6 & 7 & 8 & 9 & \\
\hline 1.Cow & 70 & 80 & 65 & 137 & 230 & 115 & 200 & 198 & 220 & 1315 \\
\hline 2.Oxen & 5 & 120 & 42 & 161 & 600 & 210 & 250 & 230 & 240 & 1938 \\
\hline 3.Buffalo & 50 & 160 & 78 & 90 & 363 & 117 & 150 & 120 & 150 & 1278 \\
\hline 4.Goat & 45 & 212 & 250 & 300 & 510 & 317 & 360 & 320 & 370 & 2684 \\
\hline 5.Pig & 20 & 25 & - & - & - & - & 50 & 40 & 60 & 195 \\
\hline 6.Chicken & 300 & 550 & 605 & 500 & 670 & 800 & 200 & 190 & 210 & 4025 \\
\hline Total & 570 & 1147 & 1040 & 1188 & 2373 & 1559 & 1210 & 1098 & 1060 & 11455 \\
\hline
\end{tabular}

Source: Village Survey, 2005

\section{USE OF FOREST PRODUCTS}

One of the environmentally positive sounds of this VDC is that the barren Sarankot hill area has been converted into forested land in few decades due to local efforts. As presented in Table 14 the distance to collect the forest products such as firewood, fodder/grass and timber is decreasing gradually during 15 years of time period. This indicates the people's awareness and participation regarding the conservation of forest area.

Table 14: Distance to collect forest products

\begin{tabular}{|l|c|c|c|c|}
\hline \multirow{2}{*}{ Forest Products } & \multicolumn{3}{|c|}{ Distance to Collect Forest Products } \\
\cline { 2 - 5 } & $15 \mathrm{yrs}$ ago & $10 \mathrm{yrs}$ ago & $5 \mathrm{yrs}$ ago & At present \\
\hline 1.Firewood & $4 \mathrm{Km}$ & $3 \mathrm{Km}$ & $2 \mathrm{Km}$ & $1 \mathrm{Km}$ \\
\hline 2.Fodder/Grass & $10 \mathrm{Km}$ & $8 \mathrm{Km}$ & $5 \mathrm{Km}$ & $2 \mathrm{Km}$ \\
\hline 3.Timber & $30 \mathrm{Km}$ & $20 \mathrm{Km}$ & $15 \mathrm{Km}$ & $15 \mathrm{Km}$ \\
\hline
\end{tabular}

Source: Village Survey, 2005

\section{OFF-FARM ECONOMIC ACTIVITIES FOR LIVELIHOOD}

A livelihood comprises capabilities, assets and activities required for a means of living (Chambers and Conway 1991). In this VDC agricultural land is one of the most important assets where occupational structure has been dominated by agriculture and directly or indirectly almost all households are associated with agricultural activities. However, above 70 percent of the households do not have sufficient food supply and about 5 percent of the total households are land less. Therefore, these households are depending on farm laboring/wage earning, share cropping and tourism related activities in the VDC and in Pokhara Bazar for their livelihood. According to the survey findings, occupational structures of Sarangkot VDC has been dominated by agriculture, providing employment for 5227 (86.2 percent) people that followed by business/ hotel ( 9.4 percent) and service (7. 9 percent). Service includes employment in governmental and nongovernmental organizations and private business including lodges and hotels (Bhusal, 2010).
The livelihood diversifications of the majority of people living in Sarangkot VDC are directly related to different urban functions that are distributed in Pokhara Bazar. These urban functions including government and non government organizations are the accessible sources of short term/temporary to long term/permanent employment opportunities for their livelihood.

\section{TEMPORARY AND SEASONAL MIGRATION FOR LIVELIHOOD}

In this VDC temporary and seasonal migration is a common phenomenon where altogether 834 people (12 percent of the total population) are involved in the temporary and seasonal migration to different urban areas of Nepal and India for their livelihood earnings. As presented in the Table 15 there are 510 people (7.5 percent) migrated for up to 3 months, 181 (2.7 percent) for 3 to 6 months and 190 people (1.8 percent) were migrated for 6 to 12 months. Major destinations for the temporary and seasonal migration of the people in this VDC are Kathmandu, 
Narayanghat, Damauli and other urban centers and different urban centers in India. Seasonal migration occurs during the off-season from agricultural activities and one people earn in an average approximately NRs 3000.00/month. There are 84 people who were migrated for more than one year and destinations of these people are United Arab Emirates, Malaysia, Korea and Japan. In an average these people earn approximately NRs. 20,000.00/ month (U.S. \$ $1=98$ NRs).

Table 15: Temporary and Seasonal Migration

\begin{tabular}{|c|c|c|c|c|c|c|c|c|c|c|}
\hline Duration & & & Peopl & ligro & fron & ard & & & & Total \\
\hline & 1 & 2 & 3 & 4 & 5 & 6 & 7 & 8 & 9 & $\begin{array}{c}\text { (\% of total } \\
\text { population) }\end{array}$ \\
\hline $\begin{array}{l}\text { Up to } 3 \\
\text { Months }\end{array}$ & 50 & 60 & 65 & 44 & 46 & 65 & 50 & 55 & 75 & $510(7.5)$ \\
\hline 3 to 6 Months & 30 & 25 & 15 & 19 & 18 & 22 & 17 & 14 & 21 & $181(2.7)$ \\
\hline $\begin{array}{l}6 \text { to } 12 \\
\text { Months }\end{array}$ & 12 & 9 & 16 & 13 & 25 & 7 & 12 & 10 & 15 & 119 (1.8) \\
\hline $\begin{array}{l}\text { More than } 1 \\
\text { Year }\end{array}$ & 12 & 6 & 8 & 11 & 15 & 5 & 7 & 9 & 11 & $84(1.2)$ \\
\hline Total & 104 & 100 & 104 & 87 & 104 & 99 & 86 & 88 & 62 & 834 (12.3) \\
\hline
\end{tabular}

Source: Village Survey, 2005.

\section{REMITTANCE FROM NEPAL, INDIAN AND BRITISH ARMY}

In this VDC one of the sources of income for some of the local people is the remittance/pension from the British and Indian army. Altogether there are 129 people are working presently in Nepal, Indian and British army (Table 16). Also there are 60 persons from Nepal army and 55 persons from Indian army are retired and they receive pension from Nepal and Indian Governments regularly that is supporting for their livelihood.

\section{Table 16: No of people in soldiers}

\begin{tabular}{|l|c|c|}
\hline \multicolumn{1}{|c|}{ Name of Army } & $\begin{array}{c}\text { No of People } \\
\text { Working }\end{array}$ & $\begin{array}{c}\text { No of } \\
\text { People } \\
\text { Retired }\end{array}$ \\
\hline Nepal Army & 50 & 60 \\
\hline Indian Army & 75 & 55 \\
\hline British Army & 4 & - \\
\hline $\begin{array}{l}\text { Total (\% of Total } \\
\text { Population ) }\end{array}$ & 129 & 110 \\
\hline
\end{tabular}

Source: Village Survey, 2005.

\section{TOURISM RELATED ACTIVITIES SUPPORTING LIVELIHOOD}

Eco-tourism is one of the basic phenomena in this VDC where local people have considered the tourism as one of the most important source of earnings to support their livelihood. Most of the local people in this VDC have been involved in this sector directly/indirectly: some have involved as hotel/ lodge and restaurant owners/workers, some as handicrafts and souvenir shopkeepers and some as tourist guides/porter. These are the tourism related economic activities in this VDC that are supporting in the livelihoods of local community (Bhusal, 2010). Paragliding is one of the tourism activities in this VDC where local people have some opportunity in order to earn for their livelihood support.

Tourism has played a positive role in changing women's condition in the VDC where women are involved in managing hotel/restaurant, souvenir shop, kirana/cold drinks shop and in small cottage industries, Ama Samuha (Mothers Groups) and other local women groups are involving in the area of skill development for women who can produce a number of tourism related goods by mobilizing local resources. Local people felt that residence of Sarangkot who are associated with tourism activities (including women) have notably learnt to respond their business in foreign language, especially in English.

\section{CONCLUSION}

In this VDC only 21 percent of the total households have sufficient agricultural production for 9 to 12 months. Therefore, majority of the households are 
dependent on the animal husbandry and off-farm economic activities (e.g. operation of hotels/lodges, wage labor porter, tourist/trekking guide and so on) for their livelihoods. Poverty alleviation has always remained as a major challenge for overall development in Nepal and Sarangkot VDC also is under such circumstances where tourism can be a successful vehicle for overall development of the area (Bhusal, 2010). A prospect of eco-tourism in the Sarangkot VDC is high in terms of the available of tourism resources and easily accessibility. In this contest, eco-tourism can provide better opportunities in order to support for better livelihood of the people living in this VDC. A number of problems are that are hampering to attract the tourists for longer time/over night stay in the VDC. The government and local organizations have to take incitation to solve these problems.

\section{REFERENCES}

Bhusal, N. P. 2010 Role of Tourism in Local Development : A Case of Sarangkot Hill-Top in Pokhara, Western Nepal, The Third Pole: Journal of Geography, 8-10

Campbell, J. G. 2008. Sustainable mountain development: Reflection on supporting the development policies in the Himalayas. In Rasul, G. \& Karki, M. (Eds.) Policy Priorities for Sustainable Mountain Development. ICIMOD: Lalitpur.

Chambers, R., and Conway, G. 1991. Sustainable Rural Livelihoods: what Contribution Can We Make? London: DFID

Morse, S., McNamara, N. and Moses, A. 2009. Sustainable Livelihood Approach: A Critical Analysis of Theory and Practice. Geographical Paper No. 189. Department of Geography, University of Readings, UK.

Ian, S. 1998. Sustainable Rural Livelihoods: A Framework for Analysis. IDS Working Paper 72, UK. 